\title{
PERANCANGAN BUKU CERITA TENTANG BANGUNAN PENINGGALAN ZAMAN PENJAJAHAN KOLONIAL BELANDA DI KOTA SURABAYA
}

\author{
Novi Nugroho ${ }^{1}$ \\ Benny Rahmawan Noviadji ${ }^{1}$ \\ Christyan Budi Susilo ${ }^{1}$ \\ Institut Informatika Indonesia, Surabaya ${ }^{l}$ \\ pastinoviug@gmail.com
}

\begin{abstract}
Abstrak
Kota Surabaya zaman penjajahan kolonial Belanda, merupakan kota yang dikelilingi oleh tembok, kawasan dalam tembok inilah yang dikenal sebagai Kota Bawah (Benedenstaad) atau Soerabaia Lama (Oud Soerabaia), kawasan tersebut kini menjadi lingkungan cagar budaya, namun hingga saat ini masih terdapat bangunan peninggalan zaman penjajahan kolonial Belanda yang kurang terawat, bahkan masyarakat Surabaya khususnya para generasi muda banyak yang tidak mengenali sejarah bangunan peninggalan kolonial Belanda tersebut. Maka perlunya peracangan buku cerita tentang bangunan peninggalan zaman penjajahan kolonial Belanda di Kota Surabaya, dengan menggunakan teknik ilustrasi digital. Perancangan buku cerita tersebut terbagi menjadi 3 seri meliputi, seri 1 dan 2 yang membahas mengenai kawasan Eropa, serta seri 3 mengenai kawasan Pecinan dan Arab, hal ini bertujuan untuk menjadi sarana informasi serta edukasi untuk masyarakat kota Surabaya untuk mengenal sejarah bangunan zaman kolonial Belanda. Dengan adanya buku cerita ini diharap bisa menumbuhkan rasa nasionalisme serta rasa cinta terhadap kota Surabaya, khususnya para generasi muda.
\end{abstract}

Kata kunci: Buku Cerita, Sejarah, Surabaya, Ilustrasi

\begin{abstract}
Surabaya city in the the Dutch colonial periods is a city surrounded by walls, the area within the wall is known as the Lower Town (Benedenstaad) or Soerabaia Lama (Oud Soerabaia). Today, that area is a cultural heritage environment, but until now there are still buildings the relic of the Dutch colonial era is less maintained, even Surabaya people, especially the younger generation who do not recognize the history of the Dutch colonial heritage buildings. So the necessity of story bookcase about the building of colonial Dutch
\end{abstract}


heritage in Surabaya, using digital illustration technique. The design of the story book is divided into 3 series covering, series 1 and 2 that discuss about the European region, as well as series 3 regarding Chinatown and Arab region, it aims to become a means of information and education for the people of Surabaya to know the history of the building of the Dutch colonial era. With the story, the book is expected to foster a sense of nationalism and a sense of love for the city of Surabaya, especially the younger generation.

Keywords: Story book, Historical, Surabaya, Ilustration

\section{PENDAHULUAN}

Terbentuknya sebuah kota bukanlah waktu yang singkat serta peristiwa masa lalu yang menjadikan cerita sejarah sebuah kota. Pembangunan kota Surabaya diawali dengan masuknya Perusahaan Perdagangan Hindia Belanda, Verenigde Oostindisch Compangnie (VOC) pada tahun 1617. Belanda melakukan pembangunan di Surabaya pada tahun 1678, dimulai dari Benteng Belvedere (sisi kiri sungai Kali Mas). Beberapa tahun kemudian dibangunlah komplek kota Soerabaia Belanda yang dikelilingi oleh tembok, kawasan dalam tembok inilah yang di kenal sebagai Kota Bawah (Benedenstad) atau Soerabaia Lama (Oud Soerabaia), yang kini merupakan kawasan cagar budaya (Nanang, 2006). Namun hingga saat ini masih ada bangunan atau cagar budaya peninggalan zaman kolonial Belanda yang kurang terawat, bahkan masyarakat Surabaya khususnya para generasi muda banyak yang tidak mengenali sejarah bangunan peninggalan kolonial Belanda tersebut.

Maka berdasarkan permasalahan diatas, diperlukan sebuah solusi untuk pengetahuan masyarakat kota Surabaya terhadap sejarah bangunan peninggalan kolonial Belanda di kota Surabaya, dengan memberikan pengetahuan tentang sejarah bangunan dalam bentuk buku cerita dengan teknik ilustrasi digital yang dipadukan dengan unsur foto dan naskah.

Perancangan buku cerita bertujuan untuk menjadi sarana informasi serta edukasi untuk masyarakat kota Surabaya, sehingga mengenal sejarah bangunan zaman kolonial Belanda. Dengan adanya buku cerita ini diharap bisa menumbuhkan rasa nasionalisme serta rasa cinta terhadap kota Surabaya, khususnya para generasi muda. 


\section{KAJIAN TEORI}

\section{Tembok Kota Surabaya Zaman Penjajahan Kolonial Belanda}

Belanda melakukan pembangunan di Soerabaia (Surabaya) pada tahun 1678, dimulai dari Benteng Belvedere (sisi kiri sungai Kali Mas). Beberapa tahun kemudian dibangunlah komplek kota Soerabaia Belanda yang di kelilingi oleh tembok, kota tersebut dibangun oleh Verenigde Oostindisch Compangnie (VOC) untuk mendukung aktivitas perdagangannya, kawasan dalam tembok inilah yang di kenal sebagai Kota Bawah (Benedenstad) atau Soerabaia Lama (Oud Soerabaia).

Kota Bawah secara geografis daerah tersebut dibelah oleh sungai Kalimas, di sebelah barat sungai dikenal permukiman orang Eropa, sementara itu di sebelah selatan terdapat permukiman orang Arab (Arabische Kamp) dan Cina (Chinesse Kamp), selain itu juga ada sungai Pegirian di sisi timur Kota Bawah. Tembok kota yang melingkar dari utara di sebelah jembatan Patekan, melebar ke barat-selatan (Pesapen), lalu ke arah selatan (Krembangan), ke timur (Bibis \& Cantian), dan utara (Srengganan-Tenggomong-Nyamplungan) dan kembali menyambung ke titik awal di selatan jembatan Patekan, adalah jalan Jakarta, sebelah timur sungai Kalimas (Nanang, 2006).

Meskipun saat ini situs tembok kota sudah tidak dapat di jumpai, namun bekas wilayah tembok kota tersebut masih menyiratkan sejarah Kota Bawah Surabaya, melalui gedung gagah peninggalan kolonial Belanda yang masih bisa kita jumpai di wilayah tersebut, yang menjadi saksi sejarah di masa itu.

\section{Teori Buku Cerita Bergambar}

Buku adalah salah satu media informasi yang memiliki peran yang sangat penting. Meski sekarang jaman sudah berkembang kian pesatnya dimana teknologi sekarang sudah mendominasi, akan tetapi buku sebagai sumber pengetahuan belum bisa tergantikan perannya. Selain media yang mudah untuk dijangkau dan memiliki sifat mobilitas yang tinggi, buku dapat dibaca dimana dan kapan saja.

Buku cerita bergambar adalah usaha untuk menjadikan suatu cerita menjadi lebih jelas dalam bentuk gambar pada sebuah media. Cergam, komik, atau kartun merupakan buku yang cukup populer di masyarakat khususnya pada kalangan 
remaja hingga dewasa, cerita bergambar (cergam) terdiri dari teks atau narasi yang berfungsi sebagai penjelasan dialog dan alur cerita. (Bonnie Soeherman, 2009)

\section{Teori Ilustrasi}

Ilustrasi adalah proses penggambaran objek, baik visual maupun audio dan lain-lain (Chandra, 2015). Ilustrasi dibagi menjadi dua jenis yaitu ilustrasi audio dan ilustrasi visual. Ilustrasi audio berarti musik yang mengiringi suatu pertunjukkan sandiwara di pentas, radio atau musik yang melatari film. Sedangkan ilustrasi visual atau yang lebih dikenal dengan kata lain ilustrasi yaitu gambar dapat berupa foto atau lukisan untuk membantu memperjelas isi buku, karangan, dan sebagainya; dapat juga bermakna gambar, desain, diagram untuk memperjelas halaman sampul.

Menurut Wojirsch dalam Ardi Al-Maqassary (2016), ilustrasi merupakan gambaran pesan yang tak terbaca yang dapat menguraikan cerita, berupa gambar dan tulisan, yaitu bentuk grafis informasi yang memikat. Sehingga dapat menjelaskan makna yang terkandung didalam pesan tersembunyi. Dalam Chandra (2015), Ada beberapa cara teknik dalam membuat gambar ilustrasi, yaitu dengan cara: gambar tangan (manual), dengan bantuan alat digital berupa foto dan computer, atau kombinasi dari keduanya

\section{METODE PENELITIAN}

Dalam penelitian ini untuk mendalami permasalahan yang terjadi maka dilakukan beberapa tahap penelitan yaitu: 1) Wawancara dengan narasumber untuk mendapatkan informasi yang berkualitas mengenai sejarah bangunan tersebut, serta sejarah kota Surabaya; 2) Melakukan penyebaran kuesioner sehingga mendapatkan sampel data yang mengacu pada pendapat penggemar buku cerita ilustrasi dan menyukai cerita tentang sejarah; 3) Menggali data sekunder melalui internet, buku, hingga observasi sehingga memperkuat data penelitian yang digunakan dalam perancangan nantinya. 


\section{HASIL DAN PEMBAHASAN}

\section{Konsep dan Proses Perancangan}

Sebelum melakukan perancangan buku cerita ini diperlukan sebuah konsep yang diperoleh dari penentuan keyword. Keyword diperoleh dari fenomena, problematika desain, positioning, unique selling point, serta target audiens. Sehingga diperoleh keyword yang sesuai yang akan digunakan dalam perancangan yaitu memoritage. Memo di ambil dari kata memory yang berarti menceritakan sesuatu yang berkaitan tentang masa lalu sebuah kota dengan menceritakan keberadaan bangunan bersejarah. Sedangkan kata ritage di ambil dari kata heritage disini adalah memberikan informasi serta menambah pengetahuan seseorang mengenai bangunan-bangunan bersejarah peninggalan kolonial Belanda di kota Surabaya, melalui buku cerita yang dirancang. Dalam perancangan buku cerita ini menggunakan pendekatan ilustrasi yang dipadukan unsur foto, naskah, serta penggunaan warna vintage untuk menampilkan kesan tempo dulu, dengan konsep tersebut pembaca dapat memahami cerita dengan baik.

Dalam proses perancangan media utama yaitu buku cerita yang di awali dengan pemilihan judul buku cerita, berdasarkan penelitian yang di dapat dari studi artikel, wawancara mendalam, serta buku maupun literatur. Maka judul buku yang dapat diambil adalah Pilar-Pilar Masa Lalu Kota Surabaya, yang dapat dijelaskan Pilar merupakan komponen dalam sebuah bangunan; bangunan merupakan komponen terbentuknya kawasan atau kota, jadi bangunan-bangunan kokoh dan indah yang mempunyai sejarah dalam terbentuknya sebuah kota. Kemudian dilanjutkan dengan pemilihan sub judul, sub judul pada seri pertama dan kedua yaitu kawasan Eropa, penyebutan kawasan Eropa karena dahulunya merupakan permukiman orang-orang Eropa (Belanda), begitu juga pada seri ketiga mengambil sub judul kawasan Pecinan dan Arab karena dahulunya merupakan permukiman orang-orang Cina dan Arab.

Dalam perancangan buku cerita yang terbagi menjadi 3 seri diperlukan tabel penyusunan isi buku, untuk mengetahui kebutuhan materi serta tampilan visual yang diperlukan. Karakter yang ditampilkan dalam buku cerita berguna sebagai pelengkap suasan Surabaya tempo dulu yang terdiri dari karakter laki-laki (pribumi, belanda,cina) serta karakter perempuan (jawa dan belanda), kemudian 
gaya ilustrasi yang digunakan adalah ilustrasi digital dengan teknik cat air. Kemudian tahapan dari proses desain adalah sketsa dan alternatif desain, kompreshif desain terpilih, hingga desain akhir. Berikut adalah proses pemilihan karakter yang digunakan dalam buku cerita:

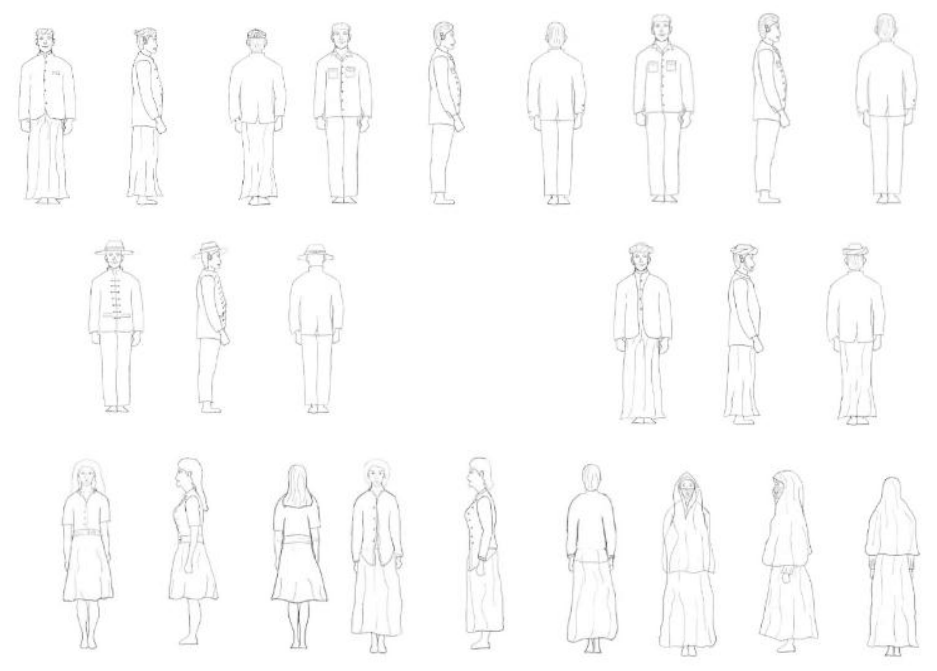

Gambar 1. Sketsa Karakter

Sumber: Dokumentasi Pribadi

Pemilihan gaya ilustrasi dilakukan mulai dari sketsa dengan menentukan bentuk sketsa yang digunakan, untuk selanjutnya proses perwarnaan.
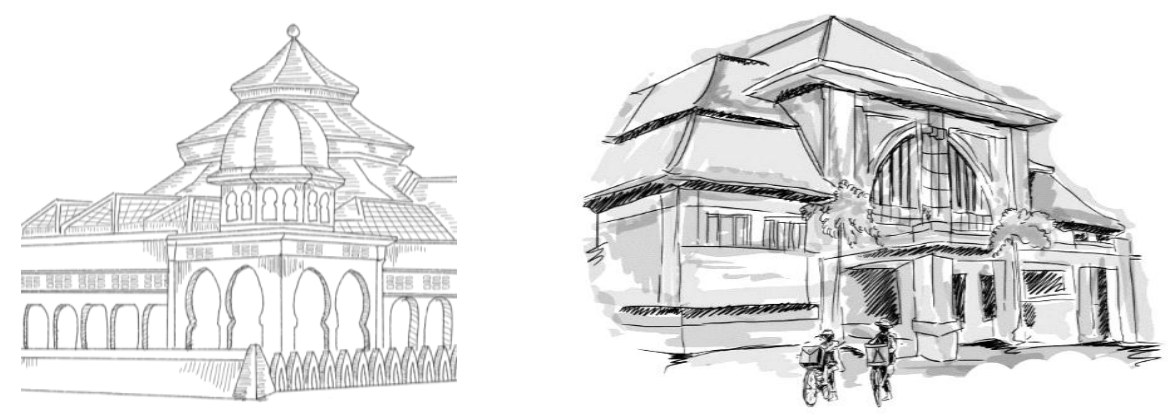

Gambar 2. Gaya Ilustrasi

Sumber: Dokumentasi Pribadi 
Pemilihan huruf dilakukan untuk medukung kesan tempo dulu, maka dilakukan seleksi dengan beberapa jenis huruf.

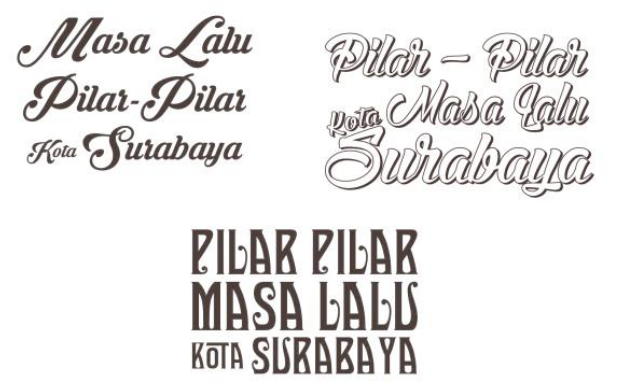

PILAR-PILAR MASA LALU

\section{KOTA SURABAYA \\ KAWASAN EROPA 1 \\ PILAR-PILAR MASA LALU KOTA SURABAYA \\ KaWASAN EROPA 1}

\section{Gambar 3. Pemilihan Huruf}

Sumber: Dokumentasi Pribadi

Pada proses ini rancangan desain telah mengalami revisi mulai dari bentuk, detail, warna dan lain-lain. Pada tahap desain akhir, desain yang telah direvisi disempurnakan lagi dan terdapat penambahan atau pengurangan. Pada tahap terakhir proses perancangan media utama buku cerita ini, desain terpilih yang telah mengalami revisi diperbaiki dan disempurnakan kembali agar hasilnya sesuai dengan konsep dan tujuan perancangan. Berikut adalah kumpulan desain terpilih:

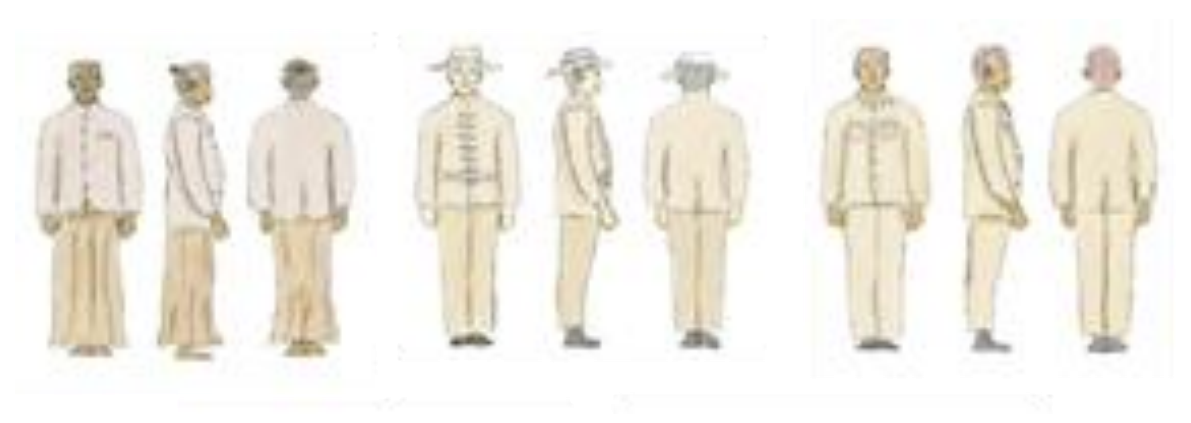



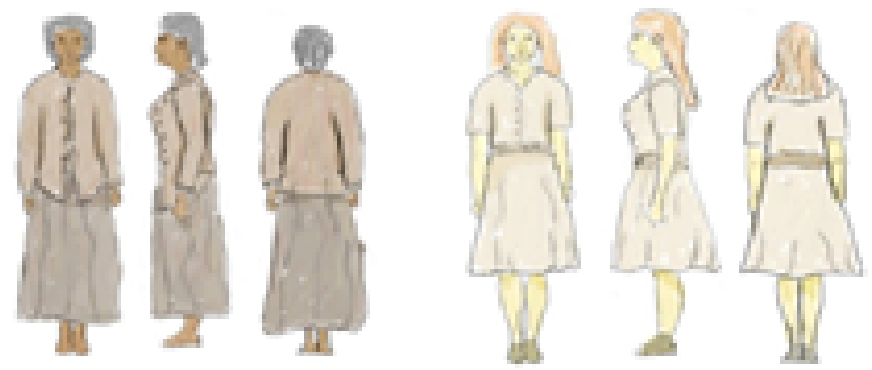

Gambar 4. Desain Terpilih Karakter

Sumber: Dokumentasi Pribadi

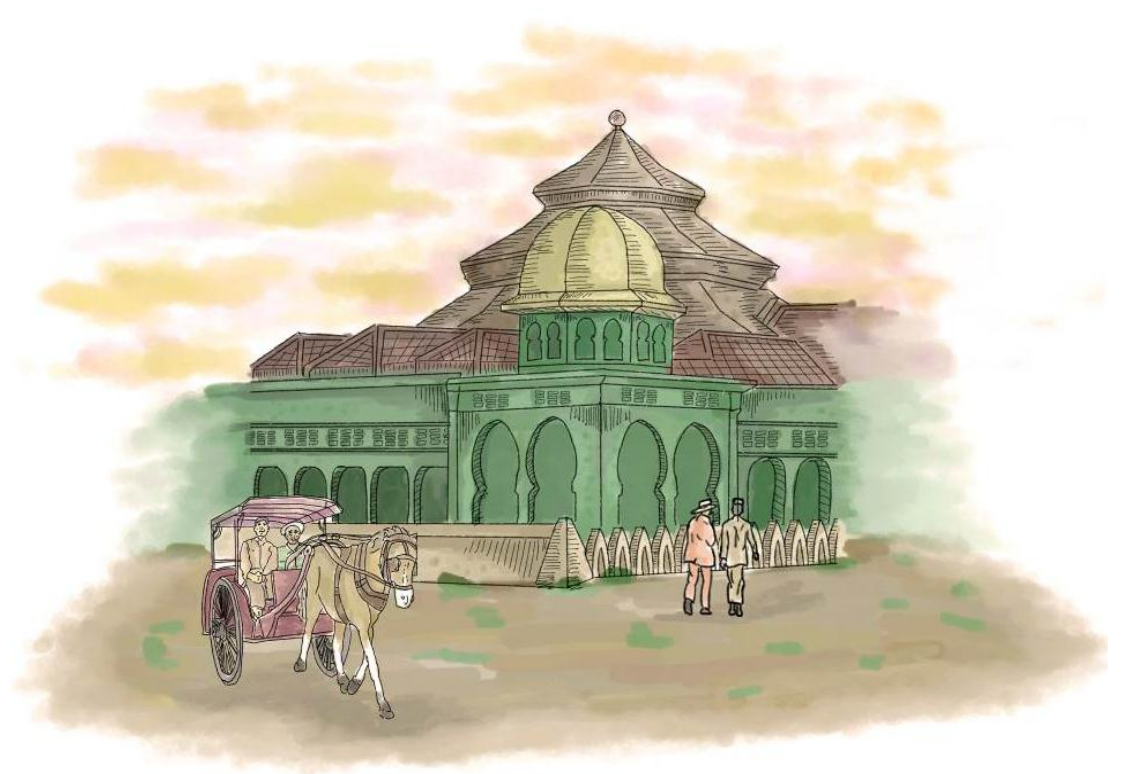

Gambar 5. Desain Terpilih Gaya Ilustrasi

Sumber: Dokumentasi Pribadi

\section{PILAR-PILAR MASA LALU \\ KOTA SURABAYA \\ KAWASAN EROPA 1 \\ Gambar 6. Desain Terpilih Huruf \\ Sumber: Dokumentasi Pribadi}



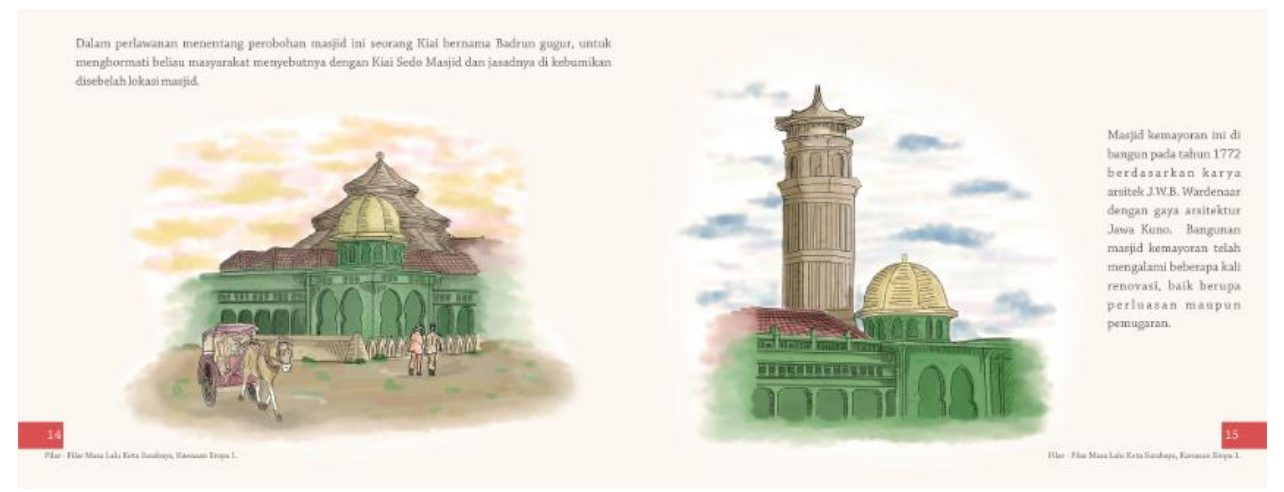

Gambar 7. Desain Terpilih Layout

Sumber: Dokumentasi Pribadi

\section{Desain Akhir}

Desain akhir merupakan hasil akhir dari proses perancangan yang sudah melalui proses penyempurnaan, dalam desain akhir ini juga menyajikan hasil rancangan merchandise berupa: $t$-shirt, topi, goodybag, stiker, pembatas buku, gelas, slayer, buku notes dan ballpoint, tempat pensil, gantungan kunci, pin, packaging box, packaging satuan, album foto, serta media promosi berupa: flyer, poster, $x$-banner sebagai media pendukung terbitnya buku.

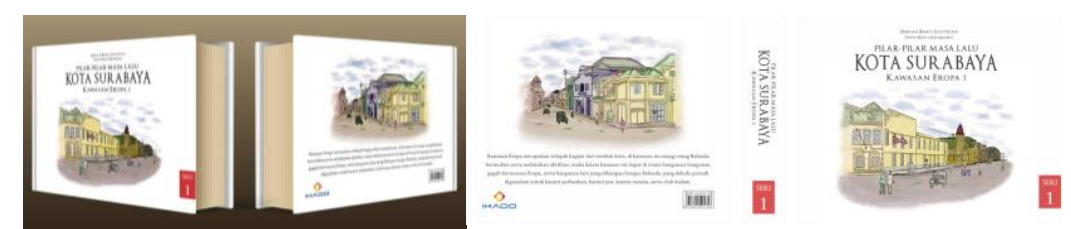

Gambar 8. Desain Akhir Cover Buku Seri 1

Sumber: Dokumentasi Pribadi

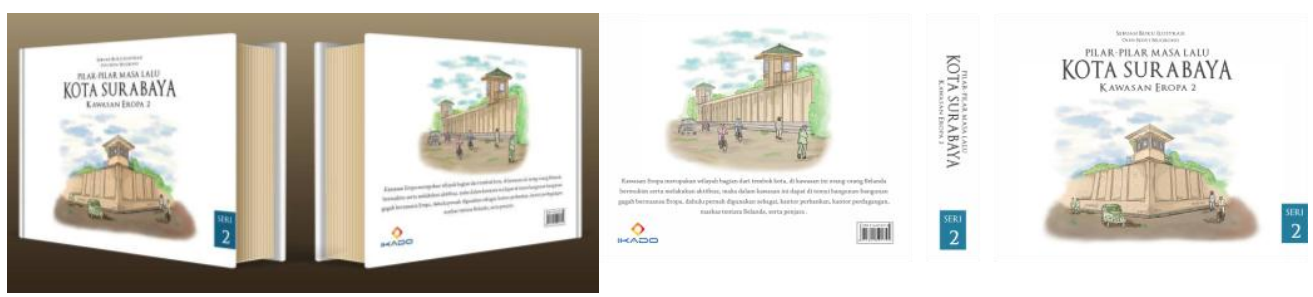

Gambar 9. Desain Akhir Cover Buku Seri 2

Sumber: Dokumentasi Pribadi 


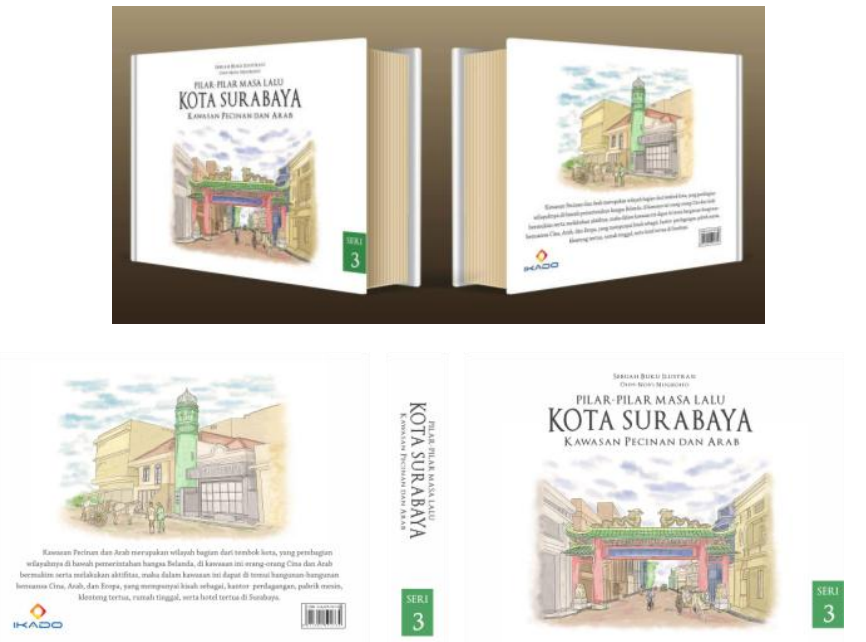

Gambar 10. Desain Akhir Cover Buku Seri 3

Sumber: Dokumentasi Pribadi

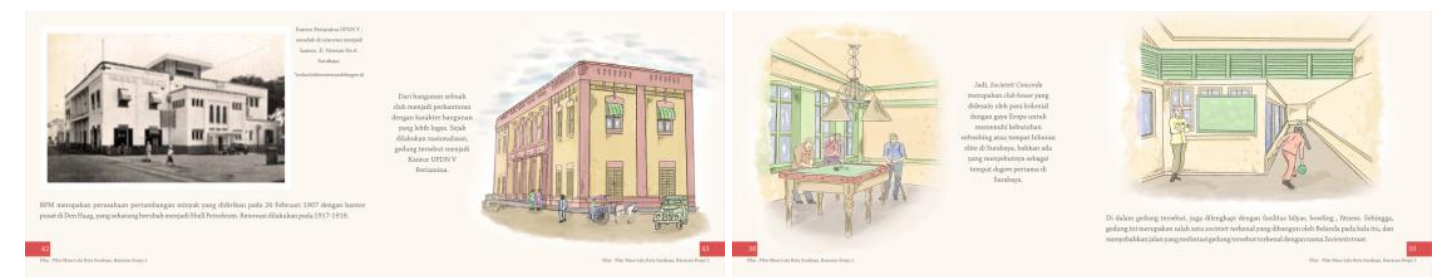

Gambar 11. Desain Akhir Layout Buku Seri 1

Sumber: Dokumentasi Pribadi

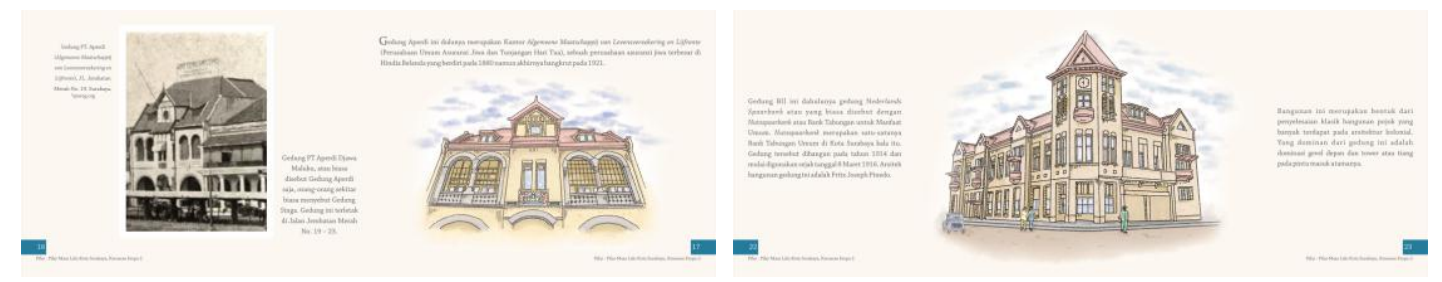

Gambar 12. Desain Akhir Layout Buku Seri 2

Sumber: Dokumentasi Pribadi 


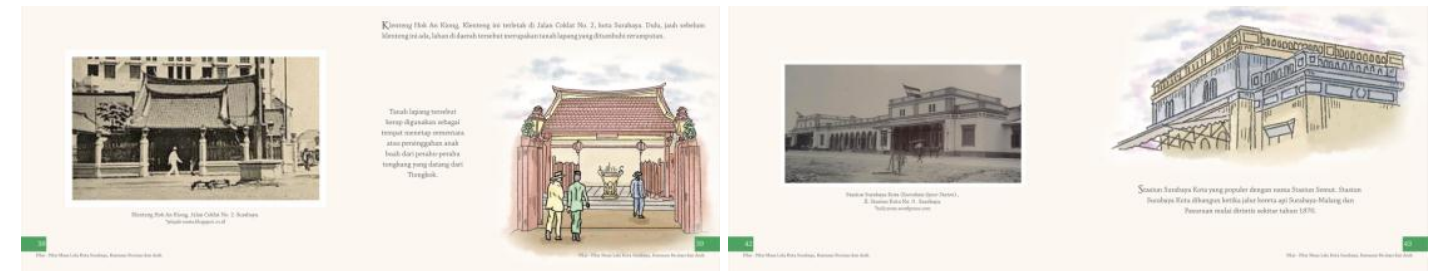

Gambar 13. Desain Akhir Layout Buku Seri 3

Sumber: Dokumentasi Pribadi
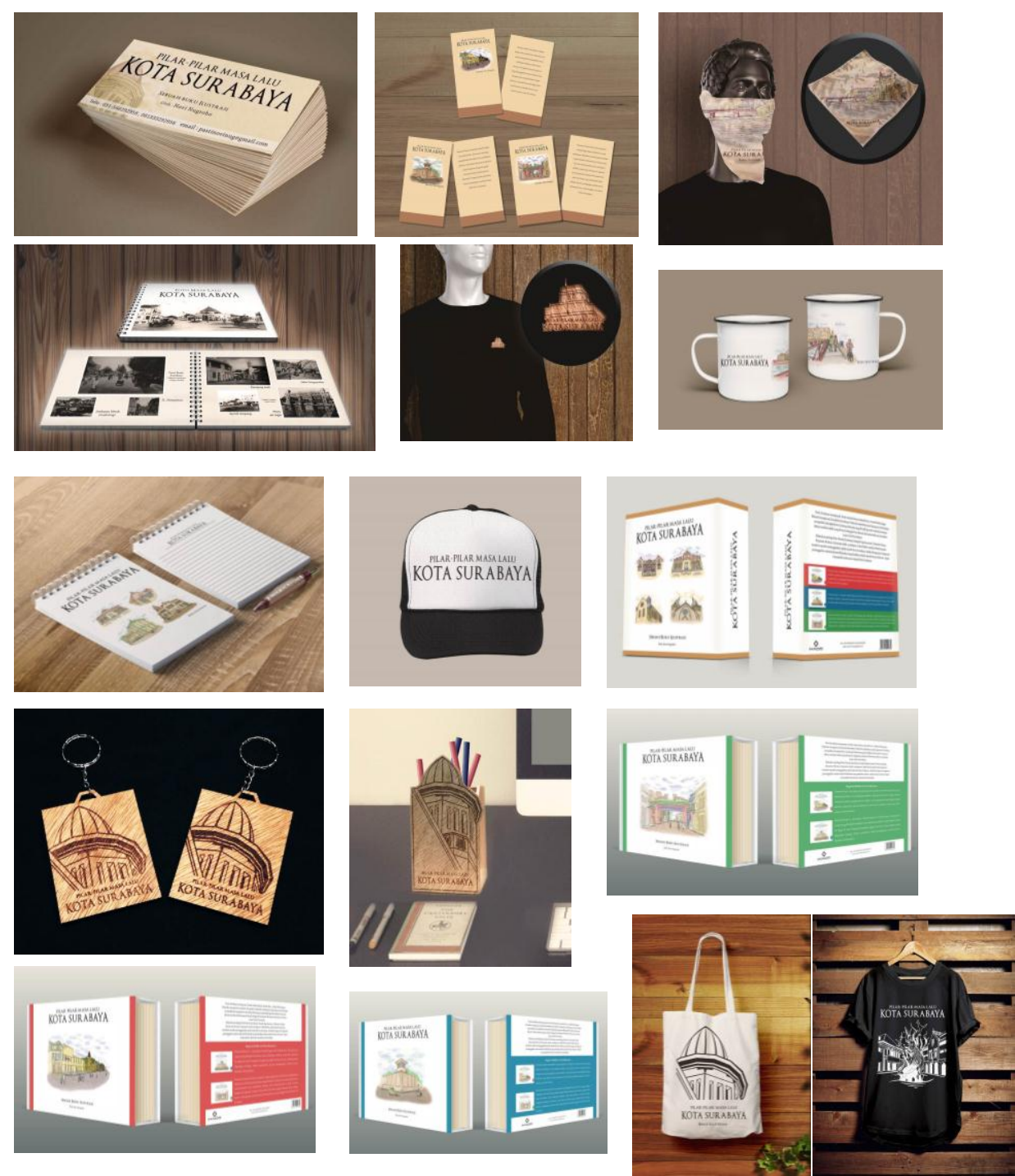

Gambar 14. Desain Akhir Merchandise

Sumber: Dokumentasi Pribadi 

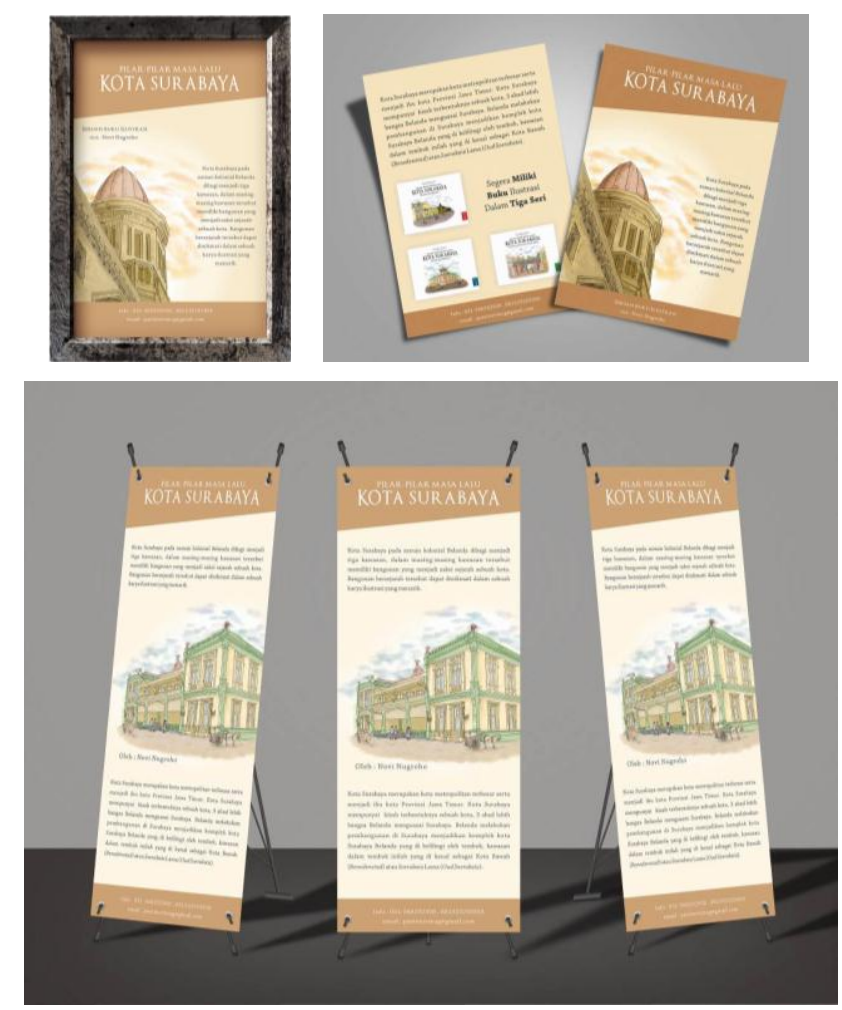

Gambar 15. Desain Akhir Media Promosi

Sumber: Dokumentasi Pribadi

\section{SIMPULAN DAN SARAN}

\section{Simpulan}

Perkembangan media berupa buku cerita kian pesat, namun buku cerita dengan penyajian ilustrasi mengenai sejarah bangunan peninggalan zaman penjajahan kolonial Belanda di kota Surabaya belum pernah di jumpai, hal ini menjadi salah satu faktor pendorong bagi penulis untuk merancang sebuah buku cerita dengan gambar ilustrasi. Dalam proses perancangan ini dibutuhkan waktu yang cukup panjang untuk menggali data sejarah bangunan, data tersebut dapat diperoleh dari, wawancara, studi literatur, internet, hingga survei lokasi.

Buku cerita ini dirancang menggunakan gambar ilustrasi digital dengan tehnik cat air, dan membagi buku cerita menjadi 3 seri yaitu (Kawasan Eropa 1, Kawasan Eropa 2, serta Kawasan Pecinan dan Arab). Dalam proses perancangan ini membutuhkan foto-foto kuno bangunan sebagai dasar ilustrasi, namun foto-foto kuno bangunan tersebut sangatlah terbatas untuk didapat, dengan mencari di 
internet, buku-buku sejarah Surabaya, hingga datang langsung ke tempat tersebut untuk mendapatkan foto yang diperlukan dalam perancangan.

Perancangan buku cerita ini sebagai media informasi dan sarana edukasi untuk masyarakat kota Surabaya khususnya para dewasa awal sehingga menumbuhkan rasa nasionalisme serta rasa cinta terhadap kota Surabaya.

\section{Saran}

Penulis menyarankan untuk mahasiswa dan pembaca yang ingin mencoba untuk membuat karya yang sama dengan hasil yang maksimal maka diperlukan ketelitian dan kejelian, serta kesabaran, baik dalam mengerjakan laporan maupun pembuatan karya, sehingga tidak terjadi kesalahan dalam penyusunan maupun hasil cetak.

Dalam proses pengerjaan laporan perancangan ini penulis masih terdapat kekurangan, tetapi penulis berharap laporan perancangan ini dapat membantu para dewasa awal, mahasiswa, serta pembaca lainnya yang ingin membuat perancangan yang sama.

\section{DAFTAR PUSTAKA}

Al-Maqassary, Ardi. 2016. Pengertian Ilustrasi. Jurnal Hasil Riset. Diakses pada tanggal 29 Oktober 2017. http://www.e-jurnal.com/2013/04/pengertianilustrasi.html

Chandra, Merlin. 2015. Kampanye Sosial Penghematan Air Di Kalangan Remaja. (Laporan Tugas Akhir). Universitas Multimedia Nusantara Tangerang.

Purwono, Nanang. 2006. Mana Sorabaia Koe. Surabaya: Pustaka Eureka.

Soeherman, Bonnie dan Wirawan, Adhicipta.R. 2009. Mastering Chibi Chracter. Jakarta: Elex Media Komputindo. 